J Hum Nutr Diet. 2015 February ; 28(0 2): 59-69. doi:10.1111/jhn.12200.

\title{
Candy consumption in childhood is not predictive of weight, adiposity measures or cardiovascular risk factors in young adults: the Bogalusa Heart Study
}

\author{
C. E. O'Neil' ${ }^{1}$, T. A. Nicklas ${ }^{2}$, Y. Liư ${ }^{2}$, and G. S. Berenson ${ }^{3}$ \\ ${ }^{1}$ Louisiana State University Agricultural Center, Baton Rouge, LA, USA \\ 2USDA/ARS Children's Nutrition Research Center, Department of Pediatrics, Baylor College of \\ Medicine, Houston, TX, USA \\ ${ }^{3}$ Department of Epidemiology, Tulane University School of Public Health and Tropical Medicine, \\ New Orleans, LA, USA
}

\begin{abstract}
Background-There are limited data available on the longitudinal relationship between candy consumption by children on weight and other cardiovascular risk factors (CVRF) in young adults. The present study investigated whether candy consumption in children was predictive of weight and CVRF in young adults.
\end{abstract}

Methods-A longitudinal sample of children 10 years $(n=355 ; 61 \%$ females; 71\% European Americans, 29\% African Americans) who partici pated in cross sectional surveys from 1973 to 1984 (baseline) and in one of two surveys (follow ups) as young adults [19-38] years; mean (SD) = 23.6 (2.6) years] in Bogalusa, LA, were studied. Dietary data were collected using $24 \mathrm{~h}$ dietary recalls at baseline and at one follow up survey; a food frequency questionnaire was used in the other follow up survey. Candy consumers were those consuming any amount of candy. Candy con sumption was calculated $\left(\mathrm{g} \mathrm{day}^{-1}\right)$ from baseline $24 \mathrm{~h}$ dietary recalls, and was used as a covariate in the adjusted linear mixed models. Dependent variables included body mass index (BMI) and CVRF measured in young adults.

Results-At baseline, $92 \%$ of children reported consuming candy [46 (45) $\mathrm{g} \mathrm{day}^{-1}$ ]; the percentage decreased to $67 \%$ [20 (30) $\mathrm{g} \mathrm{day}^{-1}$ ] at fol low up. No longitudinal relationship was shown between baseline candy consumption and BMI or CVRF in young adults, suggesting that candy consumption was not predictive of health risks later in life.

\footnotetext{
(C) 2013 The British Dietetic Association Ltd.

Correspondence C. E. O’Neil, LSU Agricultural Center, 261 Knapp, Hall, 110 LSU Union Square, Baton Rouge, LA, 70803-0106, USA., Tel.: +1 225578 1631, Fax: +1 225578 4443, coneil1@1su.edu.

Conflict of interests

The authors declare that they have no conflicts of interest.

authorship

The data used were taken from an existing data set: Bogalusa Heart Study. The data used in the present study were collected between 1973 and 1996. The Bogalusa Heart Study was designed by GSB. TAN and GSB designed the longitudinal study reported here. YL performed the data analyses. TAN, YL and CO'N evaluated the data analyses. CO'N drafted the initial manuscript with critical input from YL, TAN and GSB. All authors critically reviewed the manuscript and approved the final version submitted for publication.
} 
Conclusions-The consumption of nutrient rich foods consistent with die tary recommendations is important, although modest amounts of candy can be added to the diet without potential adverse long term consequences to weight or CVRF. Additional studies are needed to confirm these results.

\section{Keywords}

adults; Bogalusa Heart Study; candy; consumption; cardiovascular risk factors; children; weight/ adiposity

\section{Introduction}

In the USA, the prevalence of obesity has escalated over the last several decades, reaching epidemic proportions, with almost $32 \%$ of children (Ogden et al., 2012) and 70\% of adults (Flegal et al., 2012) being classed as over-weight or obese. In some populations, however, obesity appears to be levelling off (Flegal et al., 2012; Ogden et al., 2012); this is not the case in some ethnic minority groups (Flegal et al., 2012; Ogden et al., 2012). Obesity in children and adolescents is associated with significant comorbid conditions, as previously seen principally in adults, including hyperlipidaemia (Juonala et al., 2011), hypertension (Ostchega et al., 2009; Juonala et al., 2011), insulin resistance (Rank et al., 2013), the metabolic syndrome (Lloyd et al., 2012; Rank et al., 2013), type 2 diabetes (Juonala et al., 2011), obstructive sleep apnoea (Tripuraneni et al., 2013) and non alcoholic fatty liver disease (Fu et al., 2011). Overweight children and adolescents also suffer from a diminished health related quality of life (Wallander et al., 2013), bullying or teasing (Janssen et al., 2004), depression and low self esteem (Nieman et al., 2012). In adults, obesity contributes to the morbid ity and mortality from atherosclerotic cardiovascular disease (Yusuf et al., 2005; Schneider et al., 2010), hypertension (Krause et al., 1998; Okosun et al., 1999), stroke (Walker et al., 1996; Rexrode et al., 1997), type 2 diabetes (Eeg Olofsson et al., 2009; Nguyen et al., 2012), some forms of cancer (LeRoith et al., 2008), the metabolic syndrome (Park et al., 2003; Palaniappan et al., 2004), obstructive sleep apnoea (Vgontzas et al., 1994; Peppard et al., 2000) and non alcoholic fatty liver disease (Karlas et al., 2013). In adults, obesity also affects quality of life, increases medical costs and increases job absenteeism (Burton et al., 1999; Ford et al., 2001; Bungum et al., 2003; Cawley \& Meyerhoefer, 2012); the direct and indi rect costs associated with obesity in adults are estimated at $\$ 209$ billion or $20.6 \%$ of US healthcare expenditures (Cawley \& Meyerhoefer, 2012).

The most straightforward cause of obesity is that over time energy intake exceeds energy expenditure. In reality, however, the causes of obesity are more complex and can be genetic (Xia \& Grant, 2013), environmental (e.g. poverty) (Bambra et al., 2013), the result of a lack of access to nutrient rich foods (Budzynska et al., 2013)), as well as behavioural [e.g. lack of physical activity (Heinonen et al., 2013), screen time (Wethington et al., 2013) and dietary (Rolls, 2012)]. The prevalence of obesity and potential severity of its consequences have created the impetus to identify an immediate and simple solution to this complex problem. Despite the multifactorial causes of obesity, there remain those who advocate simplistic approaches to curb the obesity epidemic: notably, that single foods, food groups, or nutrients are the cause of obesity and should be avoided. 
Added sugars are defined as those sugars added during food processing, food preparation or at the table by the consumer (Fitch \& Keim, 2012). Major food sources of added sugars include soft drinks, fruit drinks, cakes, cookies, pies, dairy desserts and candy (Fitch \& Keim, 2012; O'Neil et al., 2012; Keast et al., 2013). Although added sugars have been implicated in obesity, the evidence is inconsistent (Malik et al., 2006; Johnson et al., 2007; Welsh \& Cunningham, 2011; Wang et al., 2013a). High intakes of added sugars have also been reported to have adverse effects on cardiovascular risk factors (CVRF), including blood pressure (Feig et al., 2008; Bremer et al., 2009; Nguyen et al., 2009); very low density lipoprotein cholesterol, high density-lipoprotein-cholesterol (HDL C), and triglyceride levels (Hellerstein, 2002; Mensink et al., 2003; Appel et al., 2005; Stanhope et al., 2009); and insulin resistance (Stanhope et al., 2009); however, these results are also inconsistent (Van der Schaaf et al., 1999; Howard et al., 2006).

Most examining the association of consumption of added sugars and CVRF, including obesity, have only included sugar sweetened beverages (Morgan, 2013) or fructose (Bray \& Popkin, 2013). Candy is a major source of added sugars in the diet (National Cancer Institute, 2010; Keast et al., 2013); some candies (notably chocolate candy) are also a source of dietary saturated fatty acids (SFA) (O'Neil et al., 2011a,b). However, there are only a few cross sectional studies that have examined candy consumption and its association with CVRF (O'Neil et al., 2011a,b; Murphy et al., 2013); the results obtained have shown no positive association with CVRF, including weight, in candy consumers. Longitudinal studies are needed to confirm the lack of a predictive relationship between candy consumption and CVRF.

The Bogalusa Heart Study (BHS) (Berenson et al., 1980; Berenson, 1986), conducted in Bogalusa, Louisiana, and beginning in 1973, is a long-term epidemiological study aiming to examine the early natural history of heart disease in a well defined, biracial [European American (EA) and African American (AA)], pediatric population (Berenson, 2001). Data collection conducted in cohorts of children aged 10 years and follow ups with participants as young adults have provided the opportunity to study the longitudinal prediction of diet and CVRF in this population from 1973 to 1996. The objective of the present study was to determine whether candy consumption in childhood was predictive of the presence of adverse levels of CVRF, including weight/adiposity measures, in young adulthood in participants of the BHS.

\section{Materials and methods}

\section{Overview of the Bogalusa Heart Study}

Dietary intake, anthropometric data and CVRF were col lected from children who were aged 10 years in the 1973-74, 1976-77 or 1978-79 initial cross sectional surveys (baseline). Follow up data were collected in 1989-1991 when participants were young adults aged 1928 years ( $n=247 ; 58 \%$ female, 67\% EA, 33\% AA; mean age 23 years) and in 19951996 when participants were $19-38$ years $(n=222 ; 62 \%$ female; $71 \%$ EA and $29 \%$ AA; mean age 29 years). Participants in the two longitudinal samples, which were combined, did not overlap. Total energy intake and candy consumption at follow up were used as covariates in the adjusted analyses (Table 1). 
The present study was reviewed and approved by the Louisiana State University and Tulane University Medical Centers Institutional Review Boards. Written informed consent was obtained from the children's parent or guardian prior to participation in the baseline surveys, and from the young adults in the follow up surveys.

\section{Collection of dietary information}

Dietary information from children aged 10 years was determined using a single 24-h dietary recall; the methodology was adapted for interviewing children and found to be a reliable and valid method (Farris \& Nicklas, 1993). Participants aged 10 years completed the recall interview immediately prior to the lunch meal at school. Quality controls, which improved the reliability and validity of the data, were rigidly applied to all aspects of the study and are reported elsewhere (Frank et al., 1984, 1986; Nicklas, 1995). The first follow-up study (1989-1991) also used 24-h dietary recalls to determine intake. Candy $\left(\mathrm{g} \mathrm{day}^{-1}\right)$ consumption at baseline and from the first fol low up survey was obtained from 1 day 24-h dietary-recall. Duplicate recalls were obtained from $10 \%$ random subsamples of each study population to assess interviewer variability (Frank et al., 1986). Candy was defined as chocolate bars or packets (e.g. Hershey bars or M\&Ms), other chocolate candy bars (e.g. Snickers) or sugar candy (e.g. Lifesavers).

Candy consumption from the second young adult follow up survey was obtained from the youth/adoles cent questionnaire (YAQ), a 131 food item, self admin istered, semi quantitative food frequency questionnaire (Rockett et al., 1995, 1997), which was used to deter mine dietary intake in the young adults participating in the 1995-1996 follow up study. All interviewers partici pated in rigorous training sessions and pilot studies before the field surveys to minimise interviewer effects. The YAQ is valid and reliable for use in epidemiologi cal studies (Rockett et al., 1995, 1997) and its use in one of the BHS study follow up surveys has been described previously (Yoo et al., 2004; Deshmukh-Taskar et al., 2009).

Candy consumers were defined as those participants consuming any amount of candy on the day of the 24-h recall or on the YAQ. A serving of candy, from the YAQ was $40 \mathrm{~g}$, which, in turn, was based on information from the Nutrition Data System for Research.

Dietary quantitation of the 24-h recalls was determined by means of a computerised database. The Moore Extended Nutrients (MENu), formally known as the Extended Table of Nutrient Values, contained more than 5000 core foods and recipes and had values for 97 dietary components at the time of the survey. For each food/bev erage consumed, a food group code was assigned using a list of 21 food groups (Moore \& Goodloe, 1982). The data bank was a flexible system permitting continuous updating of existing values and additions of new single or composite foods. Periodic updates were made to the MENu to reflect nutrient changes in food products. Nutrient values included United States Department of Agriculture (USDA) data, other published references, manufacturers' information and recipe calculation by ingredients. Nutrient analysis of the YAQ was conducted by the Channing Laboratory at Brigham and Women's Hospital. 


\section{Physiological measures}

Cardiovascular risk factors, including height and weight for calculation of body mass index (BMI) (NHLBI, 2012); waist circumference, subscapular and triceps skinfold thickness; systolic and diastolic blood pressure; total and low density lipoprotein cholesterol (LDL-C), HDL-C, triglycerides; insulin, glucose and $\mathrm{C}$ reactive protein were determined using standard protocols (Berenson, 1986). Being overweight at baseline was defined using the Centers for Disease Control and Prevention's 2000 Growth Charts as a BMI at or above the 85th percentile and lower than the 95th percentile for children of the same age and sex; obesity was defined as a BMI at or above the 95th percentile for children of the same age and sex (Barlow \& the Expert Committee, 2007). In young adults (follow-up), being overweight and obese were defined as BMI from 24.9 to 29.9 and BMI $\geq 30\left(\mathrm{~kg} \mathrm{~m}^{-2}\right)$, respectively (NHLBI, 2012).

\section{Statistical analysis}

Numeric and graphic methods were used for data normal ity test. Baseline demographic characteristics were described using the mean (SD), frequencies and percentages.

Independent $\mathrm{t}$ tests for continuous variables and the chi-squared test for categorical variables were used for descriptive analyses. Longitudinal analyses were conducted to examine whether candy consumption in childhood (baseline) predicted health biomarkers in young adult-hood (follow up). Separate linear mixed models were used to detect any relationship between candy at baseline and health biomarkers at follow up using PROC MIXED in SAS, version 9.3 (SAS, Cary, NC, USA), thus allowing determination of regression coefficients for various predictors at the same time as adjusting for estimated errors for the repeated measurements. All models were adjusted for baseline measures, age, sex, race/ethnicity, total energy, lifestyle variables (e.g. smoking status and alcohol use) and baseline CVRF. Because of the unequal spacing observation, the length of the subjects' from baseline to the follow-up survey and candy consumption at follow up were also included as an additional covariate in the each model. All statistical analyses were run using SAS. $P<0.05$ (twotailed) was considered statistically significant.

\section{Results}

\section{Study population and candy consumption}

Only subjects ( $n=355 ; 61 \%$ female; $71 \%$ EA) with baseline and follow up data were included in the final analytic sam ple (Table 1). At baseline, approximately $77 \%$ of the popu lation were under or normal weight, with approximately $14 \%$ and $9 \%$ being overweight and obese, respectively. At follow-up, only 55\% of the population was under or normal weight, and approximately $28 \%$ and $18 \%$ were over-weight or obese, respectively. At baseline, approximately $92 \%$ of the population consumed candy, with a mean (SD) candy intake of 46.45 (45.1) $\mathrm{g} \mathrm{day}^{-1}$. At follow-up, approximately $67 \%$ of the population were candy consum ers with a mean (SD) intake of 19.8 (29.3) $\mathrm{g}$ day $^{-1}$. 


\section{Weight/adiposity and cardiovascular risk factors}

Table 2 shows the weight/adiposity and cardiovascular risk factors at baseline and followup. At baseline (child hood), mean (SD) weight and BMI were 36.0 (9.0) kg and 18.0 (3.3) $\mathrm{kg} \mathrm{m}^{-2}$, respectively. At follow-up (adult hood), mean (SD) BMI was $25.6(6.1) \mathrm{kg} \mathrm{m}^{-2}$; weight and waist circumference (WC) were $75.9(19.5) \mathrm{kg}$ and $81.0(14.2) \mathrm{cm}$, respectively.

At baseline, mean (SD) systolic and diastolic blood pres sure levels were 100.7 (8.7) $\mathrm{mmHg}$ and 61.5 (7.4) $\mathrm{mmHg}$, respectively. Total, HDL C, LDL-C values were 165.1 (26.8), 62.8 (21.3) and 93.9 (24.8) $\mathrm{mg} \mathrm{dL}^{-1}$, respectively. Glucose and insulin values were 82.2 (6.9) $\mathrm{mg}$ $\mathrm{dL}^{-1}$ and 10.5 (7.4) $\mu \mathrm{U} \mathrm{mL} \mathrm{L}^{-1}$, respectively. At follow-up, mean (SD) systolic and diastolic blood pressure levels were 110.0 (10.3) $\mathrm{mmHg}$ and 70.7 (9.0) $\mathrm{mmHg}$, respectively. Total, HDL C and LDL C values were 181.3 (35.6), 51.6 (12.8) and 114.9 (31.6) $\mathrm{mg} \mathrm{dL}^{-1}$, respectively. Glucose and insulin values were $79.3(9.1)$ and $11.2(7.3) \mu \mathrm{U} \mathrm{mL}^{-1}$, respectively (Table 2).

\section{Effect of candy consumption on weight status, anthropometric and metabolic risk factors}

Table 3 shows that there was no association between candy consumption at baseline or at follow-up and weight, BMI or any CVRF examined. Table 4 shows the least square mean (SE) of weight and CVRF at follow-up when the population was stratified into tertiles using candy consumption at baseline. Candy consumption at baseline was in the ranged 0.00-19.5 $\mathrm{g}$ (tertile 1) to $54.8-281.5 \mathrm{~g}$ (tertile 3). Table 5 shows the lack of predictive ability between candy consumption in childhood with any weight or CVRF in young adults at follow-up (tertile 1 was the reference group).

\section{Discussion}

The present study confirmed previous results obtained from cross sectional studies (O'Neil et al., 2011a,b; Murphy et al., 2013), indicating that candy consumption was not associated with weight/adiposity or CVRF, including objective measures of blood pressure, cholesterol and triglycerides, or glucose and insulin in children or adults. The present study extended these cross sectional analyses by also showing that candy consumption in childhood did not predict adult obesity/adiposity or CVRF when they were young adults.

The present study also showed that the prevalence of candy consumption and the actual amount consumed by the BHS population at baseline were higher than reported previously in a nationally representative sample. O'Neil et al. (2011a), using data from the National Health and Nutrition Examination Survey (NHANES) 1999-2004, showed that approximately $32 \%$ of children aged $2-13$ years consumed candy, and those that did consumed $35.2 \mathrm{~g} \mathrm{day}^{-1}$. This may reflect secular trends in candy consumption among children. Using BHS data, Nicklas et al. (2004) showed that candy consumption by children aged 10 years decreased significantly over the seven separate cross sectional studies of the BHS. In survey years 1973-1974, 94\% of children consumed candy, whereas, in 19931994 , only $71 \%$ of these children consumed candy. O'Neil et al. (2011a) looked at data from 1999 to 2004 and also at a different age range of children, which may also have resulted in the reported difference with respect to candy consumption. 
The prevalence of young adults who consumed candy in the present study was higher than reported previously (approximately 20\%), although the amount consumed was lower (38 g day $^{-1}$ ) (O'Neil et al., 2011b). The results of the present study are similar to another analysis of BHS data showing that $93 \%$ of children and $58 \%$ of young adults consumed candy and also that the amounts consumed were similar to those of the present study (Demory-Luce $e t$ al., 2004). Overall differences between BHS data and the NHANES data may reflect the small sample size and the limited geographical area from which BHS data were collected; only data from children 10 years of age being collected in BHS; secular trends in diet; or the varying dietary methods and nutrient databases that were used in these studies. However, the notably higher intake in children in the present study should have increased any potential predictive ability between candy consumption and obesity and CVRF in young adults.

Surprisingly, the results obtained in studies that have looked at the association of the consumption of added sugars and obesity have been inconsistent (Malik et al., 2006; Johnson et al., 2007, 2009; Welsh et al., 2010; Wang et al., 2013a). The consumption of added sugars, how ever, has been adversely associated with several CVRF (Welsh et al., 2010) including increased triglyceride levels, decreased HDL C levels, and, in women, increased LDL-C. This association with CVRF has led the American Heart Association to recommend that added sugars intake be limited to 418.4 and $627.6 \mathrm{~kJ} \mathrm{day}^{-1}$ (100 and 150 $\mathrm{kcal} \mathrm{day}^{-1}$ ) for adult females and males, respectively (Johnson et al., 2009). This recommendation is much lower than that of the Institute of Medicine, which recommends that energy from added sugars intake not exceed 25\% of total energy intake (Institute of Medicine of the National Academies, 2002). In addition to added sugars, chocolate candy also contains SFA; these have long been associated with CVRF and cardiovascular disease (USDA, 2010). However, in adults, the consumption of chocolate candy has been associated with a $19 \%$ decreased risk of LDL C and a $15 \%$ reduced risk of the metabolic syndrome (O'Neil et al., 2011b). This suggests that either the amount of added sugars or SFA consumed in candy was not sufficient to adversely affect levels of CVRF or other factors in chocolate candy, such as phyto-chemicals, were cardioprotective.

Previous studies have shown that candy consumers have higher intakes of energy and added sugars than non candy consumers (O'Neil et al., 2011a,b; Murphy et al., 2013); adult candy consumers also had higher intakes of SFA than nonconsumers (O'Neil et al., 2011b; Murphy et al., 2013). Why is that these three cross sectional studies and the present longitudinal study do not show an association with obesity or CVRF? One possible reason is that the other studies suggest that candy may not be a significant source of energy or added sugars in the diet (Welsh et al., 2011; Murphy et al., 2013; Keast et al., 2013; NCI, 2010b). Information on added sugar intakes is not available from the BHS data; however, data from the NHANES has shown that, in children and adults, candy accounted for only approximately 1.6 and 1.2 teaspoons of added sugars in the diet (NCI, 2010b). Furthermore, candy ranks as the 14th contributor to SFA intake in the diet, and provides approximately $3.1 \%$ of the total SFA in the population aged 2 years and older (NCI, 2010a).

It is also possible that the population studied was too young to show significant changes in CVRF. On average, all CVRF in adults, with the exception of BMI, were within normal limits. As an example of the low rates of chronic disease in this age group, a previous study 
of BHS data showed that the incidence of type 2 diabetes in the 18-29-year old age group was only $1.6 \%$ (Nguyen et al., 2012). This low level of disease is unlikely to influ ence the mean results.

\section{Strengths and limitations}

The three principal strengths of the present study are that the BHS is a well studied group of individuals with a relatively large sample size. In addition, the present study is a longitudinal study with a stronger study design than the previously published cross sectional studies that have looked at candy consumption and health outcomes. Finally, the present longitudinal study is unique in that it is the only study that has looked at the effect of candy consumption in child-hood on CVRF in adults

However, Bogalusa, LA, is a small Southern city and its residents may not be representative of the US population. Furthermore, despite the large sample size, AA participants, especially AA males, were under-represented. At follow-up, two different methods of dietary assessment were used. Both methods of dietary assessment have inherent limitations: 24-h dietary recalls and food frequency questionnaires are memory dependent and subjects may under or over report what is consumed. The selective under reporting of foods known to be high in foods containing fats, carbohydrates or sugars (Krebs-Smith et al., 2000), as well as foods with a 'negative health image', such as candy, may be greater than the under reporting of other foods (Macdiarmid \& Blundell, 1998). For the 24-h dietary recalls, the single day intake used in the present study may not represent the usual intake by individuals over time. However, a single 24-h dietary recall is appropriate when reporting mean group intakes (Thompson \& Byers, 1994). The YAQ, as used for some of the follow-up dietary assessment, was originally developed for the dietary assessment of adolescents; however, it has been successfully used in other studies of young adults (Yoo et al., 2004; DeshmukhTaskar et al., 2009). Moreover, in young adults, energy intake measured using the YAQ or a 24-h dietary recall was similar (Nicklas, 1995). The same methodology (24-h dietary recalls) was used to collect baseline data and, although two different methods were used to collect dietary intake at follow-up, these were treated as covariates only. Other factors that may affect weight/adiposity measures and other CVRF, such as physical activity levels, were not available for use as covariates. Lastly, the data used in the presnt study were collected between 40 and 15 years ago; thus, dietary data, especially those collected at baseline, may not reflect current eating patterns. However, it is not uncommon to publish studies using data from longitudinal epidemiological studies that were collected within a similar time frame (Wang et al., 2013a,b).

\section{Conclusions}

The levels of candy consumption reported by the present study population were not predictive of weight/adiposity and CVRF. The consumption of nutrient rich foods consistent with dietary recommendations is important (USDA, 2010), although foods such as candy can be added to the diet, in modest amounts, without any potential adverse long-term health consequences. More studies, especially those conducted using more recent nationally representative data sets, are needed to confirm the results of the present study. 


\section{Acknowledgments}

The Bogalusa Heart Study is a joint effort of many indi viduals whose cooperation is gratefully acknowledged. We are particularly grateful to the participants of the present study. This work is a publication of the United States Department of Agriculture (USDA/ARS) Children's Nutrition Research Center, Department of Pediatrics, Baylor College of Medicine, Houston, Texas. The contents of this publication do not necessarily reflect the views or policies of the USDA, nor does any mention of trade names, commercial products or organisations imply endorsement by the US government.

\section{sources of funding}

The Bogalusa Heart Study was supported by grants HD-061437 and HD-062783 from the National Institute of Child Health and Human Development; 0855082E from American Heart Association; and AG-16592 from the National Institute on Aging. Addi tional support for this study was obtained from the National Confectioners Association and the USDA/ ARS through specific cooperative agreement 58-6250-6-003. Partial support was also received from the USDA Hatch Project LAB 93951. The funding sources had no input into the study design or the interpretation of the results.

\section{References}

Appel LJ, Sacks FM, Carey VJ, Obarzanek E, Swain JF, Miller ER III, Conlin PR, Erlinger TP, Rosner BA, Laranjo NM, Charleston J, McCarron P, Bishop LM, the OmniHeart Collaborative Research Group. Effects of protein, monounsaturated fat, and carbohydrate intake on blood pressure and serum lipids: results of the OmniHeart randomized trial. JAMA. 2005; 294:2455-2464. [PubMed: 16287956]

Bambra CL, Hillier FC, Moore HJ, Cairns-Nagi JM, Summerbell CD. Tackling inequalities in obesity: a protocol for a systematic review of the effectiveness of public health interventions at reducing socioeconomic inequalities in obesity among adults. Syst. Rev. 2013; 2:27. [PubMed: 23663955]

Barlow SE, the Expert Committee. Expert committee recommendations regarding the prevention, assessment, and treatment of child and adolescent overweight and obesity: summary report. Pediatrics. 2007; 120:S164-S192. [PubMed: 18055651]

Berenson, GS. Causation of Cardiovascular Risk Factors in Children: Perspectives on Cardiovascular Risk in Early Life. Raven Press; New York, NY: 1986.

Berenson GS, The Bogalusa Heart Study Investigators. Bogalusa Heart Study: a long-term community study of a rural biracial (black/white) population. Am. J. Med. Sci. 2001; 322:293-300. [PubMed: 11876192]

Berenson, GS.; McMahan, CA.; Voors, AW.; Webber, LS.; Srinivasan, SR.; Frank, GC.; Foster, TA.; Blonde, CV. Cardiovascular Risk Factors in Children: The Early Natural History of Atherosclerosis and Essential Hypertension. Oxford University Press; New York, NY: 1980.

Bray GA, Popkin BM. Calorie sweetened beverages and fructose: what have we learned 10 years later? Pediatr. Obes. 2013; 8:242-248. [PubMed: 23625798]

Bremer AA, Auinger P, Byrd RS. Relationship between insulin resistance associated metabolic parameters and anthropometric measurements with sugar sweetened beverage intake and physical activity levels in US adolescents: findings from the 19992004 National Health and Nutrition Examination Survey. Arch. Pediatr. Adolesc. Med. 2009; 163:328-335. [PubMed: 19349561]

Budzynska K, West P, Savoy-Moore RT, Lindsey D, Winter M, Newby P. A food desert in Detroit: associations with food shopping and eating behaviours, dietary intakes and obesity. Public Health Nutr. 2013; 7:1-10.

Bungum T, Satterwhite M, Jackson AW, Morrow JR. The relationship of body mass index, medical costs, and job absenteeism. Am. J. Health Behav. 2003; 27:456-462. [PubMed: 12882439]

Burton WN, Chen CY, Schultz AB, Edington DW. The costs of body mass index levels in an employed population. Stat. Bull. Metrop. Insur. Co. 1999; 80:8-14. [PubMed: 10418077]

Cawley J, Meyerhoefer C. The medical care cost of obesity: an instrumental variables approach. J. Health Econ. 2012; 31:219-230. [PubMed: 22094013] 
Demory-Luce D, Morales M, Nicklas T, Baranowski T, Zakeri I, Berenson G. Changes in food group consumption patterns from childhood to young adulthood: the Bogalusa Heart Study. J. Am. Diet. Assoc. 2004; 104:1684-1691. [PubMed: 15499355]

Deshmukh-Taskar PR, O’Neil CE, Nicklas TA, Yang S-J, Liu Y, Gustat J, Berenson GS. Dietary patterns associated with metabolic syndrome, sociodemographic and lifestyle factors in young adults: the Bogalusa Heart Study. Public Health Nutr. 2009; 12:2493-2503. [PubMed: 19744354]

Eeg Olofsson K, Cederholm J, Nilsson PM, Zethelius B, Nunez L, Gudbjörnsdóttir S, Eliasson B. Risk of cardiovascular disease and mortality in overweight and obese patients with type 2 diabetes: an observational study in 13,087 patients. Diabetologia. 2009; 52:65-73. [PubMed: 18985314]

Farris, RP.; Nicklas, TA. Characterizing children's eating behavior. In: Suskind, RM.; Suskind, LL., editors. Textbook of pediatric nutrition. 2nd. Raven Press Ltd; New York, NY: 1993. p. 505-516.

Feig DI, Soletsky B, Johnson RJ. Effect of allopurinol on blood pressure of adolescents with newly diagnosed essential hypertension: a randomized trial. JAMA. 2008; 300:924-932. [PubMed: 18728266]

Fitch C, Keim KS. Position of the Academy of Nutrition and Dietetics: use of nutritive and nonnutritive sweeteners. J. Acad. Nutr. Diet. 2012; 11:739-758. [PubMed: 22709780]

Flegal KM, Carroll MD, Kit BK, Ogden CL. Prevalence of obesity and trends in the distribution of body mass index among US adults, 1999-2010. JAMA. 2012; 307:491-497. [PubMed: 22253363]

Ford ES, Moriarty DG, Zack MM, Mokdad AH, Chapman DP. Self-reported body mass index and health-related quality of life: findings from the Behavioral Risk Factor Surveillance System. Obes. Res. 2001; 9:21-31. [PubMed: 11346664]

Frank GC, Hollatz A, Webber LS, Berenson GS. Effect of interviewer recording practices on nutrient intake - The Bogalusa Heart Study. J. Am. Diet. Assoc. 1984; 84:1432-1439. [PubMed: 6501751]

Frank, GC.; Webber, LS.; Farris, RP.; Berenson, GS. Dietary Data Book: Quantifying Dietary Intakes of Infants, Children and Adolescents - The Bogalusa Heart Study, 1973-1983. Louisiana State University Medical Center; New Orleans, LA: 1986.

Fu FJ, Shi HB, Liu LR, Jiang P, Liang L, Wang CL, Liu XY. Non-alcoholic fatty liver disease: an early mediator predicting metabolic syndrome in obese children? World J. Gastroenterol. 2011; 17:735-742. [PubMed: 21390143]

Heinonen I, Helajärvi H, Pahkala K, Heinonen OJ, Hirvensalo M, Pálve K, Tammelin T, Yang X, Juonala M, Mikkilä V, Káhoönen M, Lehtimäki T, Viikari J, Raitakari OT. Sedentary behaviours and obesity in adults: the Cardiovascular Risk in Young Finns Study. BMJ Open. 2013; 3:6.

Hellerstein MK. Carbohydrate-induced hypertriglyceridemia: modifying factors and implications for cardiovascular risk. Curr. Opin. Lipidol. 2002; 13:33-40. [PubMed: 11790961]

Howard BV, Van Horn L, Hsia J, Manson JE, Stefanick ML, Wassertheil-Smoller S, Kuller LH, LaCroix AZ, Langer RD, Lasser NL, Lewis CE, Limacher MC, Margolis KL, Mysiw WJ, Ockene JK, Parker LM, Perri MG, Phillips L, Prentice RL, Robbins J, Rossouw JE, Sarto GE, Schatz IJ, Snetselaar LG, Stevens VJ, Tinker LF, Trevisan M, Vitolins MZ, Anderson GL, Assaf AR, Bassford T, Beresford SA, Black HR, Brunner RL, Brzyski RG, Caan B, Chlebowski RT, Gass M, Granek I, Greenland P, Hays J, Heber D, Heiss G, Hendrix SL, Hubbell FA, Johnson KC, Kotchen JM. Low-fat dietary pattern and risk of cardiovascular disease: the Women's Health Initiative Randomized Controlled Dietary Modification Trial. JAMA. 2006; 295:655-666. [PubMed: 16467234]

Institute of Medicine of the National Academies. Dietary Reference Intakes for Energy, Carbohydrate, Fiber, Fat, Fatty Acids, Cholesterol, Protein, and Amino Acids. 2002 Available at: http:// www.iom.edu/Reports/2002/Dietary-Reference-Intakes-for-Energy-Carbohydrate-Fiber-Fat-FattyAcids-Cholesterol-Protein-and-Amino-Acids.aspx (accessed on 11 July 2013).

Janssen I, Craig WM, Boyce WF, Pickett W. Associations between overweight and obesity with bullying behaviors in school-aged children. Pediatrics. 2004; 113:1187-1194. [PubMed: 15121928]

Johnson L, Mander AP, Jones LR, Emmett PM, Jebb SA. Is sugar sweetened beverage consumption associated with increased fatness in children? Nutrition. 2007; 23:557-563. [PubMed: 17616342]

Johnson RK, Appel LJ, Brands M, Howard BV, Lefevre M, Lustig RH, Sacks F, Steffen LM, WylieRosett J, American Heart Association Nutrition Committee of the Council on Nutrition, Physical 
Activity, and Metabolism and the Council on Epidemiology and Prevention. Dietary sugars intake and cardiovascular health: a scientific statement from the American Heart Association.

Circulation. 2009; 120:1011-1020. [PubMed: 19704096]

Juonala M, Magnussen CG, Berenson GS, Venn A, Burns TL, Sabin MA, Srinivasan SR, Daniels SR, Davis PH, Chen W, Sun C, Cheung M, Viikari JS, Dwyer T, Raitakari OT. Childhood adiposity, adult adiposity, and cardiovascular risk factors. N. Engl. J. Med. 2011; 365:1876-1885. [PubMed: 22087679]

Karlas T, Wiegand J, Berg T. Gastrointestinal complications of obesity: Non-alcoholic fatty liver disease (NAFLD) and its sequelae. Best Pract. Res. Clin. Endocrinol. Metab. 2013; 27:195-208. [PubMed: 23731881]

Keast DR, Fulgoni VL 3rd, Nicklas TA, O'Neil CE. Food sources of energy and nutrients among children in the United States: National Health and Nutrition Examination Survey 2003-2006. Nutrients. 2013; 5:283-301. [PubMed: 23340318]

Krause RM, Winston M, Fletcher BJ, Grundy SM. Obesity: impact on cardiovascular disease. Circulation. 1998; 98:1472-1476.

Krebs Smith S, Braubard B, Kahle L, Subar A, Cleveland L, Ballard-Barbash R. Low energy reporters vs others: a comparison of reported food intakes. Eur. J. Clin. Nutr. 2000; 54:281-287. [PubMed: 10745278]

LeRoith D, Novosyadlyy R, Gallagher EJ, Lann D, Vijayakumar A, Yakar S. Obesity and type 2 diabetes are associated with an increased risk of developing cancer and a worse prognosis; epidemiological and mechanistic evidence. Exp. Clin. Endocrinol. Diabetes. 2008; 116(Suppl. 1):S4-S6. [PubMed: 18777452]

Lloyd LJ, Langley-Evans SC, McMullen S. Childhood obesity and risk of the adult metabolic syndrome: a systematic review. Int. J. Obes. (Lond). 2012; 36:1-11. [PubMed: 22041985]

Macdiarmid J, Blundell J. Assessing dietary intake: who, what and why of under-reporting. Nutr. Res. Rev. 1998; 11:231-253. [PubMed: 19094249]

Malik VS, Schulze MB, Hu FB. Intake of sugar-sweetened beverages and weight gain: a systematic review. Am. J. Clin. Nutr. 2006; 84:274-288. [PubMed: 16895873]

Mensink RP, Zock PL, Kester AD, Katan M. Effects of dietary fatty acids and carbohydrates on the ratio of serum total to HDL cholesterol and on serum lipids and apolipoproteins: a meta-analysis of 60 controlled trials. Am. J. Clin. Nutr. 2003; 77:1146-1155. B. [PubMed: 12716665]

Moore, MC.; Goodloe, MH. Extended table of nutrient values (ETNV). Louisiana State University Medical Center; New Orleans, LA: 1982.

Morgan RE. Does consumption of high-fructose corn syrup beverages cause obesity in children? Pediatr. Obes. 2013; 8:249-254.

Murphy MM, Barraj LM, Bi X, Stettler N. Body weight status and cardiovascular risk factors in adults by frequency of candy consumption. Nutr. J. 2013; 12:53. [PubMed: 23631725]

National Cancer Institute. Table 5b: Mean Intake of Added Sugars \& Mean Contribution (tsp) of Various Foods Among US Population, by Age, NHANES 2005-06. 2010a Available at: http:// riskfactor.cancer.gov/diet/foodsources/added-sugars/table-5b.html (accessed on 10 July 2013).

National Cancer Institute. Table 1: Top Food Sources of Saturated Fat among US Population, 2005-2006 NHANES. 2010b Available at: http://riskfactor.cancer.gov/diet/foodsources/sat-fat/ sf.html (accessed on 10 July 2013).

National Institutes of Health, National Heart, Lung, and Blood Institute. Clinical Guidelines on the Identification, Evaluation, and Treatment of Overweight and Obesity in Adults. 1998 Available at: http://www.nhlbi.nih.gov/guidelines/obesity/ob_gdlns.pdf (accessed on 26 January 2012).

Nguyen S, Choi HK, Lustig RH, Hsu CY. Sugar-sweetened beverages, serum uric acid, and blood pressure in adolescents. J. Pediatr. 2009; 154:807-813. [PubMed: 19375714]

Nguyen QM, Xu JH, Chen W, Srinivasan SR, Berenson GS. Correlates of age onset of type 2 diabetes among relatively young black and white adults in a community: the Bogalusa Heart Study.

Diabetes Care. 2012; 35:1341-1346. [PubMed: 22399694]

Nicklas TA. Dietary studies of children and young adults (1973-1988): the Bogalusa Heart Study. Am. J. Med. Sci. 1995; 310:S101-S108. [PubMed: 7503111] 
Nicklas TA, Demory-Luce D, Yang S-J, Baranowski T, Zakeri I, Berenson G. Children's food consumption patterns have changed over two decades (1973-1994): the Bogalusa heart study. J. Am. Diet. Assoc. 2004; 104:1127-1140. [PubMed: 15215772]

Nieman P, Leblanc CM, Canadian Paediatric Society, Healthy Active Living and Sports Medicine Committee. Psychosocial aspects of child and adolescent obesity. Paediatr. Child Health. 2012; 17:205-208. [PubMed: 23543619]

Ogden CL, Carroll MD, Kit BK, Flegal KM. Prevalence of obesity and trends in body mass index among US children and adolescents, 1999-2010. JAMA. 2012; 307:483-490. [PubMed: 22253364]

Okosun IS, Prewitt TE, Cooper RS. Abdominal obesity in the United States: prevalence and attributable risk of hypertension. J. Hum. Hypertens. 1999; 13:425-430. [PubMed: 10449204]

O'Neil CE, Fulgoni VL 3rd, Nicklas TA. Association of candy consumption with body weight measures, other health risk factors for cardiovascular disease, and diet quality in US children and adolescents: NHANES 1999-2004. Food Nutr. Res. 2011a; 55:5794.

O'Neil CE, Fulgoni VL 3rd, Nicklas TA. Candy consumption was not associated with body weight measures, risk factors for cardiovascular disease, or metabolic syndrome in US adults: NHANES 1999-2004. Nutr. Res. 2011b; 31:122-130. [PubMed: 21419316]

O'Neil CE, Keast DR, Fulgoni VL, Nicklas TA. Food sources of energy and nutrients among adults in the US: NHANES 2003-2006. Nutrients. 2012; 4:2097-2120. [PubMed: 23363999]

Ostchega Y, Carroll M, Prineas RJ, McDowell MA, Louis T, Tilert T. Trends of elevated blood pressure among children and adolescents: data from the National Health and Nutrition Examination Survey 1988-2006. Am. J. Hypertens. 2009; 22:59-67. [PubMed: 19039307]

Palaniappan L, Carnethon MR, Wang Y, Hanley AJ, Fortmann SP, Haffner SM, Wagenknecht L, Insulin Resistance Atherosclerosis Study. Predictors of the incident metabolic syndrome in adults: the Insulin Resistance Atherosclerosis Study. Diabetes Care. 2004; 27:788-793. [PubMed: 14988303]

Park YW, Zhu S, Palaniappan L, Heshka S, Carnethon MR, Heymsfield SB. The metabolic syndrome: prevalence and associated risk factor findings in the US population from the Third National Health and Nutrition Examination Survey, 1988-1994. Arch. Intern. Med. 2003; 163:427-436. [PubMed: 12588201]

Peppard PE, Young T, Palta M, Dempsey J, Skatrud J. Longitudinal study of moderate weight change and sleep disordered breathing. JAMA. 2000; 284:3015-3021. [PubMed: 11122588]

Rank M, Siegrist M, Wilks DC, Langhof H, Wolfarth B, Haller B, Koenig W, Halle M. The cardiometabolic risk of moderate and severe obesity in children and adolescents. J. Pediatr. 2013; 163:137-142. [PubMed: 23434121]

Rexrode KM, Hennekens CH, Willett WC, Colditz GA, Stampfer MJ, Rich-Edwards JW, Speizer FE, Manson JE. A prospective study of body mass index, weight change, and risk of stroke in women. JAMA. 1997; 277:1539-1545. [PubMed: 9153368]

Rockett HR, Wolf AM, Colditz GA. Development and reproducibility of a food frequency questionnaire to assess diets of older children and adolescents. J. Am. Diet. Assoc. 1995; 95:336340. [PubMed: 7860946]

Rockett HR, Breitenbach M, Frazier AL, Witschi J, Wolf AM, Field AE, Colditz GA. Validation of a youth/adolescent food frequency questionnaire. Prev. Med. 1997; 26:808-816. [PubMed: 9388792]

Rolls BJ. Dietary strategies for weight management. Nestle Nutr. Inst. Workshop Ser. 2012; 73:37-48. [PubMed: 23128764]

Schneider HJ, Friedrich N, Klotsche J, Pieper L, Nauck M, John U, Dörr M, Felix S, Lehnert H, Pittrow D, Silber S, Völzke H, Stalla GK, Wallaschofski H, Wittchen HU. The predictive value of different measures of obesity for incident cardiovascular events and mortality. J. Clin. Endocrinol. Metab. 2010; 95:1777-1785. [PubMed: 20130075]

Stanhope KL, Schwarz JM, Keim NL, Griffen SC, Bremer AA, Graham JL, Hatcher B, Cox CL, Dyachenko A, Zhang W, McGahan JP, Seibert A, Krauss RM, Chiu S, Schaefer EJ, Ai M, Otokozawa S, Nakajima K, Nakano T, Beysen C, Hellerstein MK, Berglund L, Havel PJ. Consuming fructose-sweetened, not glucose-sweetened, beverages increases visceral adiposity and 
lipids and decreases insulin sensitivity in overweight/obese humans. J. Clin. Invest. 2009; 119:1322-1334. [PubMed: 19381015]

Thompson FE, Byers T. Dietary assessment resource manual. J. Nutr. 1994; 124:2245S-2317S. [PubMed: 7965210]

Tripuraneni M, Paruthi S, Armbrecht ES, Mitchell RB. Obstructive sleep apnea in children. Laryngoscope. 2013; 123:1289-1293. [PubMed: 23288669]

United States Department of Agriculture. Dietary Guidelines for Americans. 2010 Available at: http:// www.cnpp.usda.gov/DGAs2010-PolicyDocument.htm (accessed on 11 July 2013).

Van der Schaaf MR, Koomans HA, Joles JA. Dietary sucrose does not increase twenty-four-hour ambulatory blood pressure in patients with either essential hypertension or polycystic kidney disease. J. Hypertens. 1999; 17:453-454. [PubMed: 10100085]

Vgontzas AN, Tan TL, Bixler EO, Martin LF, Shubert D, Kales A. Sleep apnea and sleep disruption in obese patients. Arch. Intern. Med. 1994; 154:1705-1711. [PubMed: 8042887]

Walker SP, Rimm EB, Ascherio A, Kawachi I, Stampfer MJ, Willett WC. Body size and fat distribution as predictors of stroke among US men. Am. Jour. Epidemiol. 1996; 144:1143-1150. [PubMed: 8956626]

Wallander JL, Kerbawy S, Toomey S, Lowry R, Elliott MN, Escobar-Chaves SL, Franzini L, Schuster MA. Is obesity associated with reduced health-related quality of life in Latino, black and white children in the community? Int. J. Obes. (Lond). 2013; 37:920-925.

Wang H, Steffen LM, Zhou X, Harnack L, Luepker RV. Consistency between increasing trends in added-sugar intake and body mass index among adults: the Minnesota Heart Survey, 1980-1982 to 2007-2009. Am. J. Public Health. 2013a; 103:501-507. [PubMed: 22698050]

Wang H, Troy LM, Rogers GT, Fox CS, McKeown NM, Meigs JB, Jacques PF. Longitudinal association between dairy consumption and changes of body weight and waist circumference: the Framingham Heart Study. Int. J. Obes. (Lond). 2013b May 20. doi: 10.1038/ijo.2013.78. [Epub ahead of print].

Welsh JA, Cunningham SA. The role of added sugars in pediatric obesity. Pediatr. Clin. North Am. 2011; 58:1455-1466. [PubMed: 22093862]

Welsh JA, Sharma A, Abramson JL, Vaccarino V, Gillespie C, Vos MB. Caloric sweetener consumption and dyslipidemia among US adults. JAMA. 2010; 303:1490-1497. [PubMed: 20407058]

Welsh JA, Sharma AJ, Grellinger L, Vos MB. Consumption of added sugars is decreasing in the United States. Am. J. Clin. Nutr. 2011; 94:726-734. [PubMed: 21753067]

Wethington H, Pan L, Sherry B. The association of screen time, television in the bedroom, and obesity among school-aged youth: 2007 National Survey of Children's Health. J. Sch. Health. 2013; 83:573-581. [PubMed: 23834609]

Xia Q, Grant SF. The genetics of human obesity. Ann. N. Y. Acad. Sci. 2013; 1281:178-190. [PubMed: 23360386]

Yoo S, Nicklas T, Baranowski T, Zakeri IF, Yang S-J, Srinivasan SR, Berenson GS. Comparison of dietary intakes associated with metabolic syndrome risk factors in young adults: the Bogalusa Heart Study. Am. J. Clin. Nutr. 2004; 80:841-848. [PubMed: 15447888]

Yusuf S, Hawken S, Ounpuu S, Bautista L, Franzosi MG, Commerford P, Lang CC, Rumboldt Z, Onen CL, Lisheng L, Tanomsup S, Wangai P Jr, Razak F, Sharma AM, Anand SS, INTERHEART Study Investigators. Obesity and the risk of myocardial infarction in 27,000 participants from 52 countries: a case-control study. Lancet. 2005; 366:1540-1549. 


\section{Table 1}

Descriptive statistics Bogalusa Heart Study data at baseline* and follow-up ${ }^{*}$

\begin{tabular}{|c|c|c|c|c|}
\hline & $n$ & Baseline & $n$ & Follow-up \\
\hline $\begin{array}{l}\text { Age (years), } \\
\text { mean (SD) }\end{array}$ & 355 & $10.06(0.46)$ & 355 & $23.56(2.60)$ \\
\hline Sex, $n(\%)$ & 355 & & 355 & \\
\hline Male & & $138(38.87)$ & & \\
\hline Female & & $217(61.13)$ & & \\
\hline $\begin{array}{l}\text { Race/ethnicity, } \\
n(\%)\end{array}$ & 355 & & 355 & \\
\hline EA & & $252(70.99)$ & & \\
\hline AA & & $103(29.01)$ & & \\
\hline $\begin{array}{l}\text { Sex by race/ } \\
\text { ethnicity, } n(\%)\end{array}$ & 355 & & 355 & \\
\hline EA male & & $102(38.73)$ & & \\
\hline AA male & & $36(10.14)$ & & \\
\hline EA female & & $150(42.25)$ & & \\
\hline AA female & & 67 (18.87) & & \\
\hline $\begin{array}{l}\text { Smoking status, } \\
n(\%)\end{array}$ & & & 304 & \\
\hline Current & & NA & & $87(28.62)$ \\
\hline Nonsmokers & & NA & & $217(61.11)$ \\
\hline BMI status, $n(\%)^{*}$ & 355 & & 355 & \\
\hline Underweight & & $17(4.79)$ & & $20(5.63)$ \\
\hline Normal weight & & $258(72.68)$ & & $174(49.01)$ \\
\hline Overweight & & $48(13.52)$ & & $98(27.61)$ \\
\hline Obese & & $32(9.01)$ & & $63(17.75)$ \\
\hline $\begin{array}{l}\text { Candy consumers, } \\
n(\%)\end{array}$ & 355 & & & \\
\hline Consumers & & $326(91.83)$ & & $239(67.32)$ \\
\hline Nonconsumers & & $29(8.17)$ & & $116(32.68)$ \\
\hline $\begin{array}{l}\text { Candy consumed } \\
\left(\mathrm{g} \text { day }{ }^{1}\right) \\
\text { mean }(\mathrm{SD})\end{array}$ & 355 & 46.47 (45.07) & 321 & $19.84(29.29)$ \\
\hline Energy (kJ) & 355 & 8912 (3347) & 355 & 9553 (4406) \\
\hline Alcohol (g) & NA & NA & 355 & $16.41(\mathrm{~B} 2.29)$ \\
\hline
\end{tabular}

EA, European American; AA, African American; NA, not available.

* Baseline data were from three cross-sectional surveys (1973-1978) of children aged 9-11 years who participated in the Bogalusa Heart Study.

${ }^{*}$ Follow-up data were from two follow-up post-high school surveys: 1989-91 and 1995-96.

${ }^{+}$Underweight: body mass index $(\mathrm{BMI})<18 . \mathrm{B} \mathrm{kg} \mathrm{m}^{-2}$; normal weight: $\mathrm{BMI} \geq 18 . \mathrm{B}$ to $24.9 \mathrm{~kg} \mathrm{~m}^{-2}$; overweight: $\mathrm{BMI}_{24.9}$ to $<29.9 \mathrm{~kg}^{-2}$; obese: BMI $\geq 30 \mathrm{~kg} \mathrm{~m}^{-2}$. 


\section{Table 2}

Weight and cardiovascular risk factor outcomes in Bogalusa Heart Study participants related to candy intake and physiological factors at baseline* and follow-up ${ }^{\dagger}$

\begin{tabular}{|c|c|c|c|c|}
\hline & $n$ & Baseline & $n$ & Follow-up \\
\hline \multicolumn{5}{|l|}{ Weight/adiposity factors } \\
\hline Weight (kg) & 355 & $36.00(8.99)$ & 355 & $71.86(19.4 \mathrm{~B})$ \\
\hline $\mathrm{BMI}\left(\mathrm{kg} \mathrm{m}^{-2}\right)^{\frac{\hbar}{\xi}}$ & 355 & $17.98(3.33)$ & 355 & $25.57(6.11)$ \\
\hline $\begin{array}{l}\text { Waist } \\
\text { circumference } \\
(\mathrm{cm})\end{array}$ & NA & NA & 355 & $80.98(14.24)$ \\
\hline $\begin{array}{l}\text { Triceps skinfold } \\
(\mathrm{mm})\end{array}$ & 330 & $15.61(6.41)$ & 320 & $19.59(10.51)$ \\
\hline $\begin{array}{l}\text { Subscapular } \\
\text { skinfold (mm) }\end{array}$ & 330 & $11.79(6.67)$ & 321 & $19.50(11.20)$ \\
\hline \multicolumn{5}{|l|}{ Cardiovascular risk factors } \\
\hline $\begin{array}{l}\text { Diastolic BP } \\
(\mathrm{mmHg})\end{array}$ & 329 & $61.45(7.35)$ & 321 & $70.72(9.02)$ \\
\hline Systolic BP (mmHg) & 329 & $100.65(8.67)$ & 321 & $110.01(10.32)$ \\
\hline $\begin{array}{l}\text { Total cholesterol } \\
\left(\mathrm{mg} \mathrm{dL}^{-1}\right)\end{array}$ & 324 & $165.10(26.80)$ & 319 & $181.32(35.61)$ \\
\hline HDL-C (mg dL $\left.{ }^{-1}\right)$ & 324 & $62.76(21.25)$ & 319 & $51.58(12.75)$ \\
\hline LDL-C $\left(\mathrm{mg} \mathrm{dL}^{-1}\right)$ & 324 & $93.88(24.80)$ & 319 & $114.85(31.55)$ \\
\hline $\begin{array}{l}\text { Triglycerides } \\
\left(\mathrm{mg} \mathrm{dL}^{-1}\right)\end{array}$ & 324 & $68.14(35.08)$ & 319 & $99.06(75.51)$ \\
\hline Glucose $\left(\mathrm{mg} \mathrm{dL}^{-1}\right)$ & 184 & $82.23(6.90)$ & 268 & $79.29(9.12)$ \\
\hline Insulin $\left(\mu \mathrm{U} \mathrm{mL}^{-1}\right)$ & 94 & $10.47(7.40)$ & 316 & $11.22(7.28)$ \\
\hline
\end{tabular}

Data are presented as the mean (SD).

BP, blood pressure; HDL-C, high density lipoprotein; LDL-C, low density lipoprotein; NA, not available.

* Baseline data were from three cross-sectional surveys (1973-1978) of children aged 9-11 years who participated in the Bogalusa Heart Study.

${ }^{\dagger}$ Follow-up data were from two follow-up post-high school surveys: 1989-91 and 1995-96.

*Underweight: body mass index (BMI) <18. $\mathrm{B} \mathrm{kg} \mathrm{m}^{-2}$; normal weight: BMI $\geq 18$ to $24.9 \mathrm{~kg} \mathrm{~m}^{-2}$; overweight: BMI 24.9 to $<29.9 \mathrm{~kg} \mathrm{~m}^{-2}$; obese: BMI $230 \mathrm{~kg} \mathrm{~m}^{-2}$ (NHLBI, 2012). 
Table 3

Effect of candy consumption on weight status, anthropometric and metabolic risk factors

\begin{tabular}{|c|c|c|c|c|c|c|}
\hline \multirow[b]{2}{*}{ Dependent variables (DV) } & \multicolumn{3}{|c|}{ Candy consumption baseline } & \multicolumn{3}{|c|}{ Candy consumption follow-up } \\
\hline & $\beta(\mathbf{S E})$ & SD $\beta$ & $P$-value & $\beta$ (SE) & $\operatorname{SD} \beta$ & $P$-value \\
\hline $\operatorname{BMI}\left(\mathrm{kg} \mathrm{m}^{-2}\right)^{*}$ & $0.005(0.006)$ & 0.04 & 0.329 & $-0.004(0.009)$ & -0.02 & 0.608 \\
\hline Weight $(\mathrm{kg})^{*}$ & $0.013(0.016)$ & 0.03 & 0.410 & $-0.020(0.025)$ & -0.03 & 0.413 \\
\hline Systolic BP $(\mathrm{mm} \mathrm{Hg})^{\dagger}$ & $0.005(0.012)$ & 0.02 & 0.674 & $-0.006(0.020)$ & -0.01 & 0.776 \\
\hline Diastolic BP $(\mathrm{mm} \mathrm{Hg})^{\dagger}$ & $-0.018(0.011)$ & -0.09 & 0.108 & $0.006(0.018)$ & 0.02 & 0.732 \\
\hline Total cholesterol $\left(\mathrm{mg} \mathrm{dL}^{-1}\right)^{\dagger}$ & $0.062(0.039)$ & 0.08 & 0.116 & $-0.067(0.063)$ & -0.05 & 0.288 \\
\hline LDL-C $\left(\mathrm{mg} \mathrm{dL}^{-1}\right)^{\dagger}$ & $0.025(0.036)$ & 0.04 & $0.49 \mathrm{~B}$ & $-0.005(0.058)$ & 0.00 & 0.935 \\
\hline HDL-C $\left(\mathrm{mg} \mathrm{dL}^{-1}\right)^{\dagger}$ & $0.017(0.015)$ & 0.06 & 0.262 & $0.000(0.024)$ & 0.00 & 0.993 \\
\hline Triglycerides $\left(\mathrm{mg} \mathrm{dL}^{-1}\right)^{\dagger}$ & $0.133(0.082)$ & 0.10 & 0.106 & $-0.245(0.133)$ & -0.10 & 0.066 \\
\hline Glucose $\left(\mathrm{mg} \mathrm{dL}^{-1}\right)^{\dagger}$ & 0.02B (0.019) & 0.11 & 0.191 & $0.034(0.039)$ & 0.07 & 0.382 \\
\hline Insulin $\left(\mu \mathrm{U} \mathrm{mL}^{-1}\right)^{\dagger}$ & $0.047(0.026)$ & 0.18 & 0.081 & $0.031(0.058)$ & 0.05 & 0.591 \\
\hline
\end{tabular}

Data source: baseline and follow-up data from the Bogalusa Heart Study.

Length of follow-up = from the subject's first year in the study until the time of the young adult visit.

$\beta$, beta coefficient; BP, blood pressure; LDL-C, low-density lipoprotein cholesterol; HDL-C, high-density lipoprotein cholesterol.

* Adjusted for, baseline DV, age, sex, race, sex $\times$ race, total energy, candy consumed at follow-up, smoking status, alcohol intake, and length of follow-up.

${ }^{\dagger}$ Adjusted for baseline DV, age, sex, race, sex $\times$ race, total energy, body mass index (BMI), smoking status, alcohol intake, and length of followup. 


\section{Table 4}

Least squares mean (SE) of weight status and healthy outcomes, stratified by tertiles of candy consumption in childhood

\begin{tabular}{|c|c|c|c|}
\hline & $\begin{array}{l}\text { Tertile } \\
1=119\end{array}$ & $\begin{array}{l}\text { Tertile } \\
\mathbf{2 = 1 1 8}\end{array}$ & $\begin{array}{l}\text { Tertile } \\
\mathbf{3 = 1 1 8}\end{array}$ \\
\hline $\begin{array}{l}\text { Candy consumption } \\
\text { (baseline) range (g) }\end{array}$ & $0.00-19.50$ & $20.0-54.3$ & $54.8-281.5$ \\
\hline $\begin{array}{l}\text { Dependent variable } \\
\text { at follow-up }\end{array}$ & LS mean (SE) & LS mean (SE) & LS mean (SE) \\
\hline \multicolumn{4}{|l|}{ Weight status ${ }^{*}$} \\
\hline BMI $\left(\mathrm{kg} \mathrm{m}^{-2}\right)$ & $24.95(0.42)$ & $25.76(0.41)$ & $25.69(0.41)$ \\
\hline Weight (kg) & $70.22(1.23)$ & $72.09(1.19)$ & $71.95(1.20)$ \\
\hline \multicolumn{4}{|l|}{ Health outcomes ${ }^{\dagger}$} \\
\hline $\begin{array}{l}\text { Diastolic BP } \\
(\mathrm{mmHg})\end{array}$ & $71.49(0.86)$ & $71.28(0.81)$ & $69.33(0.84)$ \\
\hline Systolic BP (mmHg) & $110.22(0.94)$ & $109.83(0.89)$ & $109.62(0.92)$ \\
\hline $\begin{array}{l}\text { Total cholesterol } \\
\left(\mathrm{mg} \mathrm{dL}^{-1}\right)\end{array}$ & $176.72(3.01)$ & $180.47(2.94)$ & $181.19(2.98)$ \\
\hline LDL-C (mg dL $\left.{ }^{-1}\right)$ & $113.54(2.75)$ & $114.36(2.69)$ & $113.98(2.73)$ \\
\hline HDL-C (mg dL $\left.{ }^{-1}\right)$ & $49.83(1.14)$ & $50.75(1.11)$ & $51.41(1.13)$ \\
\hline $\begin{array}{l}\text { Triglycerides } \\
\left(\mathrm{mg} \mathrm{dL}^{-1}\right)\end{array}$ & $89.87(6.27)$ & $100.35(6.12)$ & $102.73(6.20)$ \\
\hline Glucose $\left(\mathrm{mg} \mathrm{dL}^{-1}\right)$ & $78.44(1.31)$ & $77.19(1.46)$ & $82.21(1.42)$ \\
\hline Insulin $\left(\mu \mathrm{U} \mathrm{mL}^{-1}\right)$ & $11.37(1.69)$ & $13.77(1.90)$ & $16.40(2.01)$ \\
\hline
\end{tabular}

Data source: baseline and follow-up data from the Bogalusa Heart Study.

Length of follow-up = from the subject's first year in the study until the time of the young adult visit.

BP, blood pressure; LDL-C, low-density lipoprotein cholesterol; HDL-C, high-density lipoprotein cholesterol.

Covariates: baseline measures, total energy, age, ethnicity, sex, sex $\times$ race, smoking status, alcohol intake, candy at follow-up, and length of follow-up.

${ }^{\dagger}$ Covariates: baseline measure, baseline body mass index (BMI), total energy, age, ethnicity, sex, sex $\times$ race, smoking status, alcohol intake, candy at follow-up, and length of follow-up. 
Table 5

The association of candy consumption at childhood with weight status and health outcomes at young adult follow-up

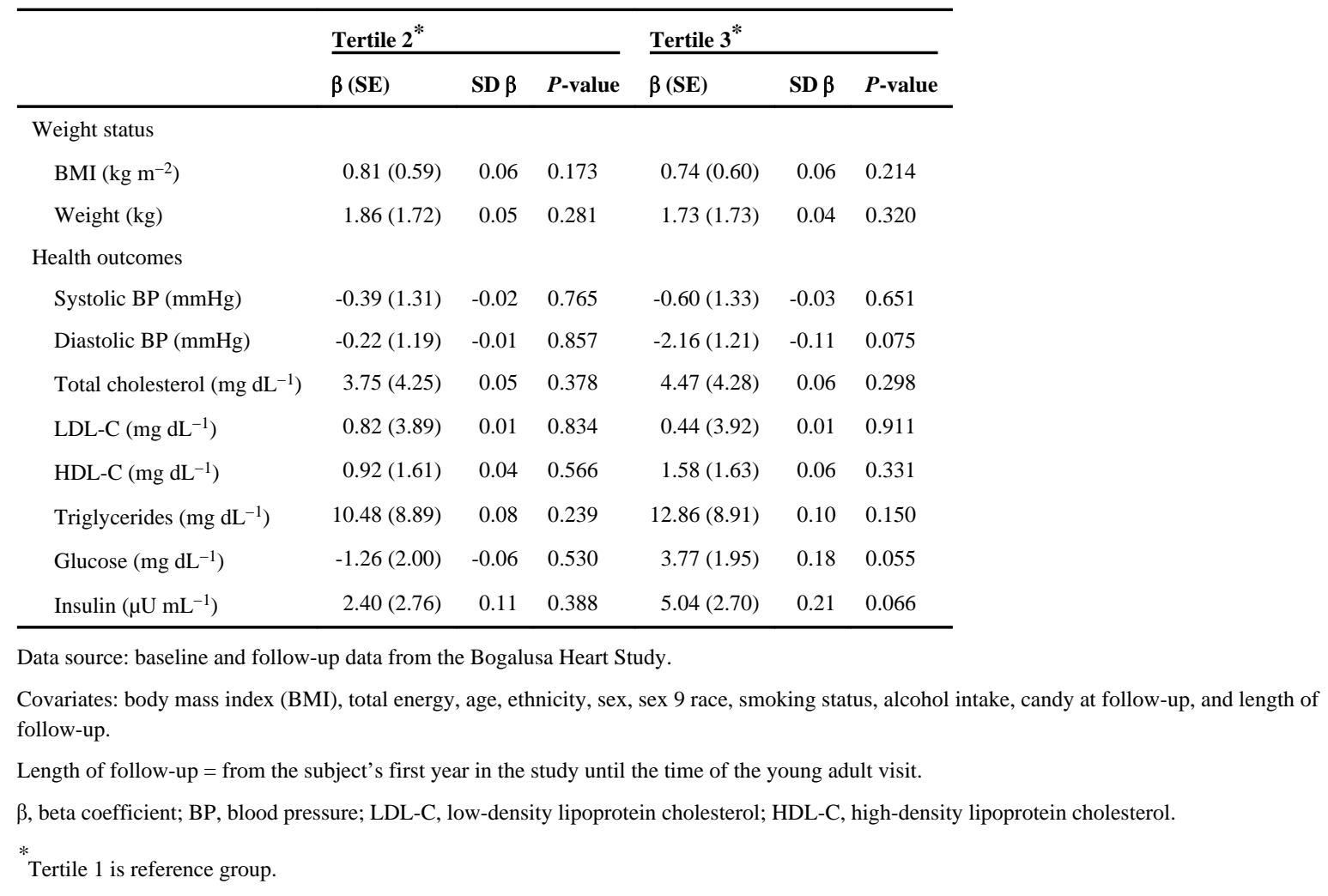

